\title{
A Cost Effective Digital Signal Controller based Maximum Power Tracking Technique for Photovoltaic Power System
}

\author{
R. Sridhar ${ }^{1 *}$, S. Jeevananthan ${ }^{2}$, Subhranshu Sekhar Dash ${ }^{1}$ and S.T. Michael ${ }^{1}$ \\ ${ }^{1}$ Department of EEE, SRM University, Tamilnadu, India \\ ${ }^{2}$ Department of EEE, Pondicherry Engineering College, Pondicherry, India \\ sridhar_eee@yahoo.co.in
}

\begin{abstract}
This paper aims at developing a simple, efficient and cost effective maximum power point tracking(MPPT) system that can be employed for stand-alone Photovoltaic (PV) applications. The power versus voltage characteristics curves of $P V$ system is non linear and variable with sun's irradiation and temperature. To maximize the power utilization from a $P V$ panel, a dynamic Perturb \& Observe $(P \& O) M P P T$ algorithm is implemented using voltage and current sensors, a boost converter with digital signal controller (ds PIC4011).In any standalone $P V$ system, the power conditioning unit receives energy from the $P V$ source there by reducing the net power generation. Considering this, the sensor circuits and the components in power conditioning unit is so rationally selected that it is not only cost effective but also consumes very less power for its operation. The suggested technique is highly advantageous in the sense it is compatible photovoltaic system with and without battery banks. Prior to hardware implementation, the proposed system was validated using Matlab/Simulink environment. The simulation and hardware results reveal that the proposed MPPT system is more efficient when compared with existing systems.
\end{abstract}

Keywords: Boost converter, Digital Signal controller, Maximum power point (MPPT), Perturb \& Observe $(P \& O)$

\section{Introduction}

Reasons such as high cost and environmental damage retrieval techniques has led to a global scenario which is inclined towards generating clean and green energy. Due to the rate of depletion of conventional energy sources, countries have started to emphasize on generating power through renewable sources such as wind energy, solar energy, tidal and biomass, etc. For instance a nation like India has set forth a mission of deploying 20,000 MW of grid connected solar power by 2022 [1]. Being a tropical country, India can make the most out of abundant energy available through the solar source. Amongst the renewable energies available, solar energy is the most preferred one due to obvious reasons such as its availability and clean nature. Though it's advantageous on many aspects, one must realize the fact that "affordability and reality" are two factors that influence solar energy. Since the power output from the PV system will keep on varying with respect to irradiation and temperature, employing a maximum power point tracking (MPPT) system is indispensable in

${ }^{*}$ Corresponding Author 
PV system these days[2].MPPT system has developed into many folds since its introduction in the year 1985. Exhaustive research work has been done on MPPT techniques for various applications [3-8]. Among all MPPT techniques the most popular techniques are perturb \& observe (P\&O) and Incremental conductance methods [9-13]. From the literature, it is inferred that MPPT technique is essential to increase the efficiency and power of the solar cell. Hence, MPPTs are pre-requisites to any solar setup and they are essential in increasingly competitive energy market. The advent of inexpensive and powerful processors has enabled more solar energy applications than ever before.

This particular work is attempted to realize the feasibility of MPPT system that can be designed for house hold PV applications. Here a low cost digital signal controller (dsPIC 4011) along with necessary sensor circuits is employed to track the peak power in the panel. The whole system-has been migrated to a cost effective one by replacing battery banks with boost converters and thereby driving the loads during day hours. If loads are mandatorily needed to be driven during non shiny period, the battery banks are included which can be charged by boost converters. Also if the loads are isolated in nature and of lower rating, then the boost converter is replaced by a buck converter. The suggested MPPT technique is so compatible that the inclusions of batteries do not make a huge difference. The sensor unit of this setup is highly energy efficient since all the sensors are self isolated from the circuit and are compatible with the controller inhibiting the use calibration units. Simulation and hardware results reveal that developing a simple, cost effective MPPT controller using the suggested methodology is highly feasible.

The paper is organized in the following manner Section II consists of PV cell modelling and its characteristic study. Section III deals with the proposed system and MPPT technique employed. Section IV discusses the results. Conclusion is given in Section V.

\section{PV Modelling}

The solar cell is the fundamental component in a solar module. By connecting the solar cells in series and parallel, the desired voltage is obtained. The magnitude of the output current $\left(\mathrm{I}_{\mathrm{ph})}\right.$ in a PV cell depends on the irradiation falling on the cell. Equivalent circuit of a PV cell is given in Figure 1.

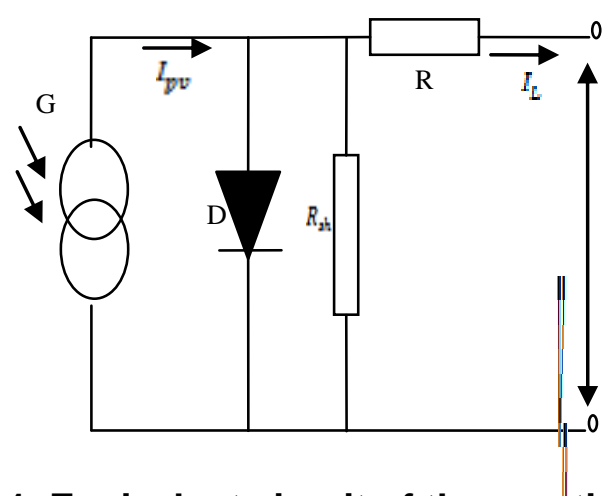

Figure 1. Equivalent circuit of the praditical PV cell 


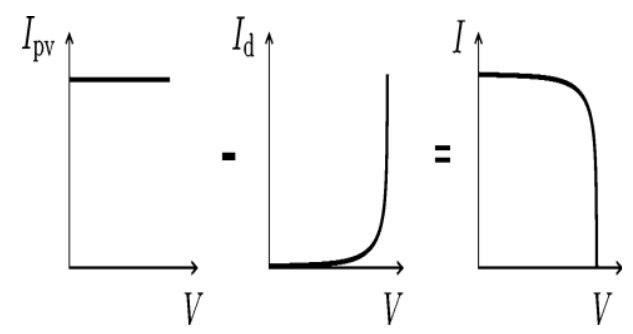

Figure 2. I-V Characteristic curve of a cell

To simulate the characteristics of the PV panel a detailed mathematical modelling of the same should be done [14-17]. The equations pertaining to the equivalent circuit are used for modelling the PV panel in a Matlab environment. From the Figure 2, the net current of the cell is the difference of the photocurrent ( $\mathrm{I}_{\mathrm{PV})}$ and the normal diode current,

$$
\begin{gathered}
I=I_{p v}-I_{d} \\
I=I_{p v}-I_{0}\left(e^{\frac{q\left(V+I R_{S}\right)}{n K T}}-1\right)
\end{gathered}
$$

The photo current relevant for a particular temperature $\left(T_{1)}\right.$ is given by

$$
\mathrm{I}_{\mathrm{pv}}\left(\mathrm{T}_{1}\right)=\mathrm{I}_{\mathrm{SC}}\left(\mathrm{T}_{\text {nom }}\right) \frac{\mathrm{G}}{\mathrm{G}_{\text {nom }}}
$$

Increase in $\mathrm{I}_{\mathrm{sc}}$ for unit increase in temperature

$$
K_{0}=\frac{I_{S C}\left(T_{2}\right)-I_{S C}\left(T_{1}\right)}{\left(T_{2}-T_{1}\right)}
$$

Diode saturation current at a given temperature

$$
I_{0}=I_{0}\left(T_{1}\right) \times\left(\frac{T}{T_{1}}\right)^{3 / n} e \frac{q V_{0}\left(T_{1}\right)}{n k\left(\frac{1}{T}-\frac{1}{T_{1}}\right)}
$$

Diode saturation current at temperature, $\mathrm{T}_{1}$

$$
\mathrm{I}_{0}\left(\mathrm{~T}_{1}\right)=\frac{\mathrm{I}_{\mathrm{SC}}\left(\mathrm{T}_{1}\right)}{\left(\mathrm{e} \frac{\mathrm{qVoc}\left(\mathrm{T}_{1}\right)}{\mathrm{nkT}_{1}}-1\right)}
$$


From the equations (5) and (6) it can be inferred that the short circuit current of a PV panel depends upon the irradiation and the open circuit voltage depends upon the temperature. This vital relation can be represented graphically by Figure 3. As the temperature increases, the open circuit voltage decreases and also the peak power increases for corresponding increase in insolation.

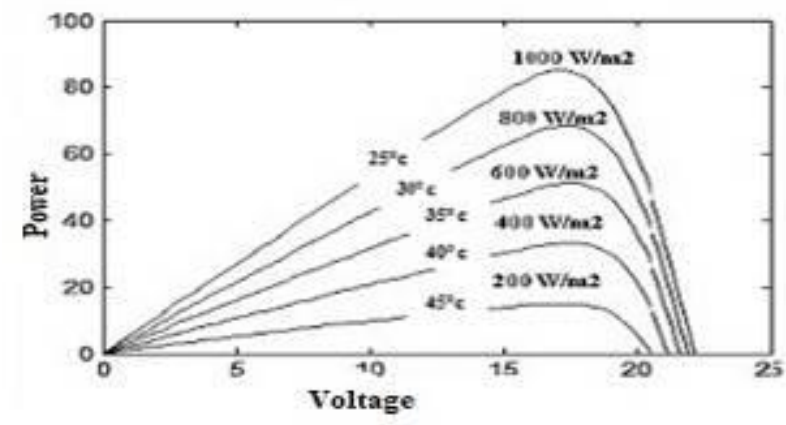

Figure 3. P-V curves' family under different irradiation and temperature levels

Table 1. Electrical characteristics data of PV Panel -WS-140

\begin{tabular}{rr}
\hline Parameters & Values \\
\hline $\begin{array}{r}\text { Maximum Power } \\
\left(\mathrm{P}_{\max }\right)\end{array}$ & $140 \mathrm{~W}$ \\
Voltage at $\mathrm{P}_{\max }$ \\
$\left(\mathrm{V}_{\operatorname{mpp}}\right)$ \\
Current at $\mathrm{P}_{\max }$ \\
$\left(\mathrm{I}_{\mathrm{mpp}}\right)$ & $17 \mathrm{~V}$ \\
Open circuit Voltage \\
$\left(\mathrm{V}_{\mathrm{oc}}\right)$ \\
Short circuit \\
current $\left(\mathrm{I}_{\mathrm{sc}}\right)$
\end{tabular}

\section{System Description}

The block diagram of the system is shown in Figure 4. The inputs (voltage, current) for the MPPT controller is fetched from the PV panel and fed to the control unit. The control unit executes perturb and observe MPPT algorithm to find the relevant duty cycle for DC-DC converter to make sure that maximum power is yielded from the panel for particular insolation and temperature. The DC-DC converter referred here is a boost converter. The converter's choice depends upon the applications and type of loads. Buck converters find its application when we use batteries as loads. 


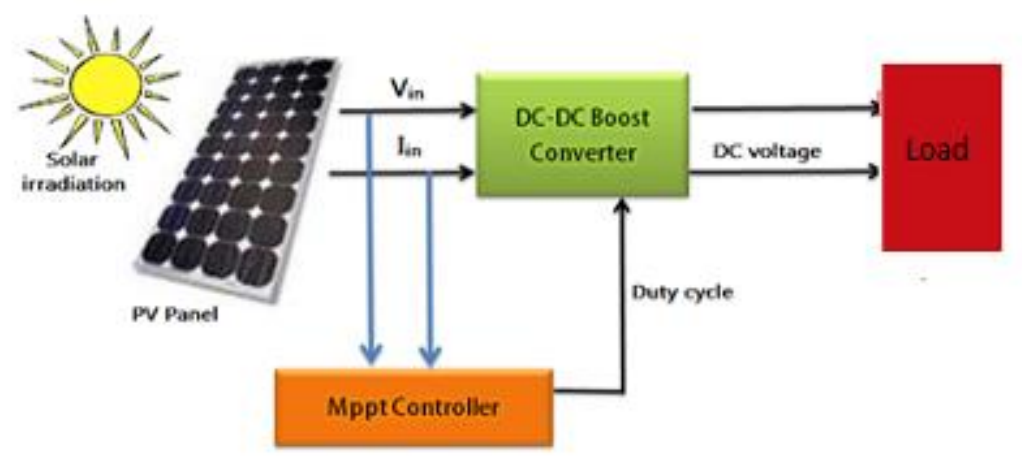

Figure 4. Block diagram of MPPT System

The $\mathrm{P} \& \mathrm{O}$ (Perturb and Observe) technique is based on a logic by which, maximum power is obtained through variation of operating voltage or current of the PV panel. Under operating condition, the technique continuously perturbs the terminal voltage while measuring output power. If the power increase in a given direction, then the peak operating point is moving towards MPP and if it decreases, then it is inferred that the operating point has crossed the peak power point and that direction should be reversed. This perturbation is done by controlling the duty cycle $(\delta)$. The advantage of only Perturb and Observe method is that when it is properly optimized it can offer very high Maximum Power Point Tracking efficiency, which is highly competitive against other Maximum Power Point Tracking algorithms. The $\mathrm{P}$ and $\mathrm{O}$ algorithm can be represented in a flow chart as shown in Figure 5

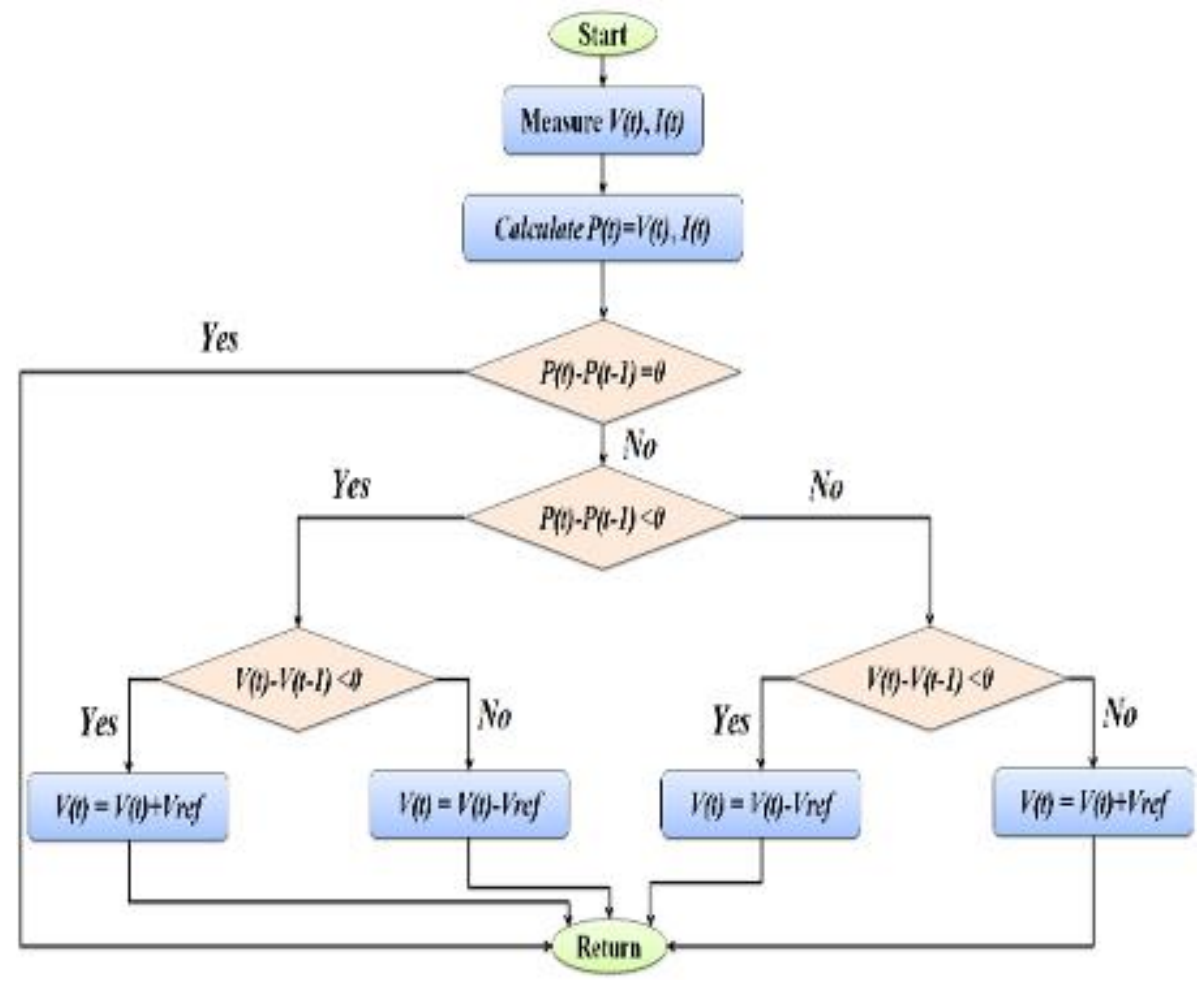

Figure 5. Flow diagram of P\&O MPPT 


\subsection{DC-DC Boost Converter}

Since the output from Solar panels is a DC voltage, DC/DC converter is used to provide the flexibility to amend the DC voltage or current at any point in the circuit. The boost converter is designed to step up a fluctuating solar panel voltage to a higher constant DC voltage. It uses voltage feedback to keep the output voltage constant and these are often preferred as they are smaller, lighter in weight, provide a high quality output and more efficient than the traditional linear power regulators [18-19]. The fundamental equation of boost converter is given

$$
\begin{gathered}
\frac{V_{\text {out }}}{I_{\text {out }}}=\frac{V_{\text {in }}}{I_{\text {in }}} \frac{(T-D)}{\left(1-D^{2}\right)} \\
R_{\text {in }}=R_{0}\left(1-D^{2}\right)
\end{gathered}
$$

The inference from the equation (9) is by varying the duty cycle, varying $R_{i n}$ can be matched with fixed $R_{\text {out }}$ there by maximum power can be extracted.

\subsection{MPPT Sensors}

The fundamental sensors that are required for employing MPPT algorithm are voltage and current sensors: Instantaneous voltage of the PV panel can be easily sensed using a signal voltage divider circuit. Figure 8(a) represents a voltage sensor circuit after proper calibration it can be provided in micro controller. A simple voltage divider circuit consists of two resistors connected in series and parallel to the PV panel. The sensed voltage value is amplified and filtered through the voltage follower operational amplifiers before it is fed in to the digital signal controller.

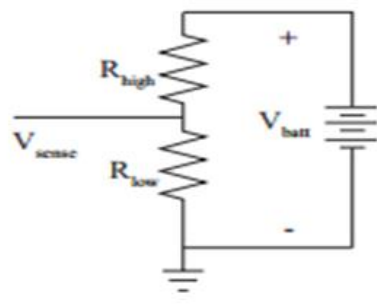

(a) Voltage sensor (b)Current Sensor

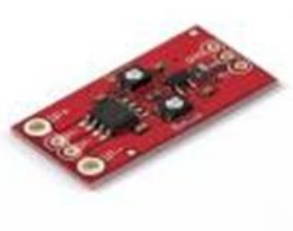

(c)Irradiation Sensor
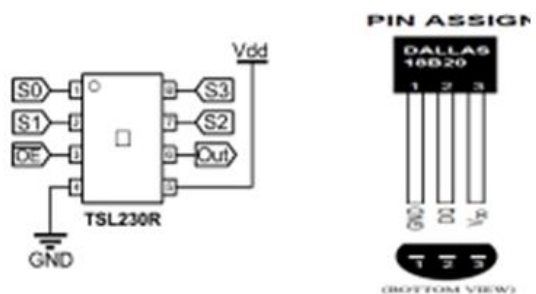

Figure 8. Sensors

The usage of current sensor is indispensable in the design of a MPPT controller but commercial current sensors are bulky and are not energy efficient. The ACS712 is a MEMS based current transformer which is very compact and energy efficient since it is self isolated. This electric sensor will be in charge of keeping track of the current that the panel outputs at all times. These readings will be fed into the microcontroller in order to provide the user with real- time values of the current. A typical current sensor employing operational amplifier is given in the Figure 8(b). But at the same time, for high voltage applications current transformer (or) Len sensor will serve the purpose. Irradiance and temperature sensor are essential to know the characteristics performance of the developed system with respect to change in ambient temperature and irradiation. Figure 8(c) shows the light to frequency 
sensor which can be calibrated to exactly measure the irradiation.DS18B20 is the temperature sensor (refer Figure 8(d))

\subsection{MPPT Algorithm in dsPIC4011}

The digital controller (dsPIC 4011) chosen for this work is meant for its high performance in handling complex calculations. The auxiliary power for the controller is derived from the PV panel voltage. The controller executes P\&O MPPT algorithm and feeds the command signal to the boost converter.

\section{Simulation and Experimental Results}

A prototype MPPT system employing ( $\mathrm{P} \& \mathrm{O})$ MPPT algorithm has been developed and tested. The PV panel which is taken for study is $140 \mathrm{~W}$ maximum power and $21.2 \mathrm{~V}$ open circuit voltage at standard test conditions. A Standard test condition here refers to a temperature of $25^{\circ} \mathrm{C}$ and an irradiation of $1 \mathrm{k} \mathrm{W} / \mathrm{m}^{2}$. To test the nature of system for varying atmospheric condition, the proposed PV MPPT system is simulated in MATLAB/SIMULINK by modelling the PV system using mathematical equation and coding MPPT in embedded Math function. Figure 9 shows the simulation results and PV output at standard test conditions. During standard test conditions, the peak power tracked is approximately equal to $140 \mathrm{w}$.Maximum power point oscillates around the peak power of $140 \mathrm{~W}$ and it correspond to a operating voltage of $16 \mathrm{~V}$. The hardware set up is shown in Figure 10. The setup have PV panel, boost converter, and microcontroller. This output of the boost converter can be fed to lamp load of $80 \mathrm{ohm}$ and the inference is tabulated in Table 2 . Figure 11 shows the comparison chart of various components used and their cost and power consumption details

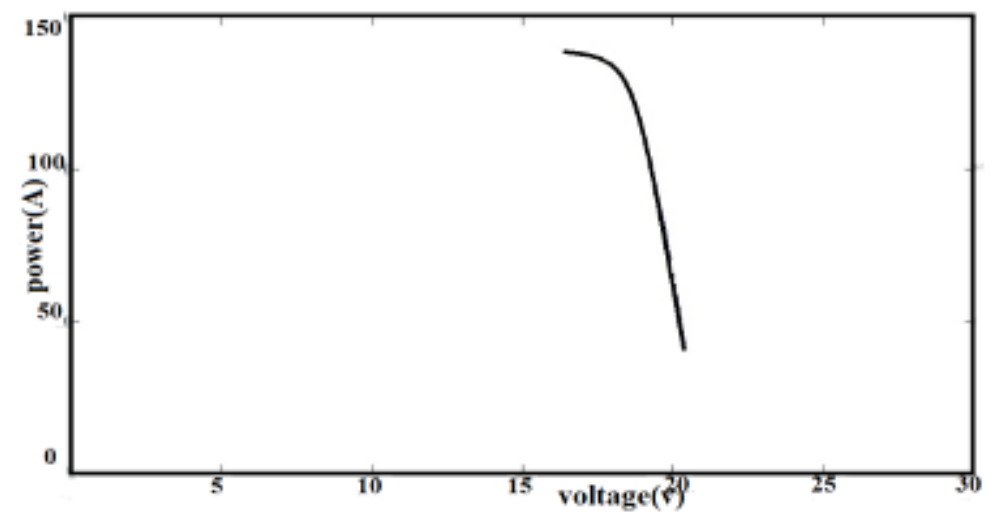

Figure 9. Peak Power tracked using P\&O Algorithm 

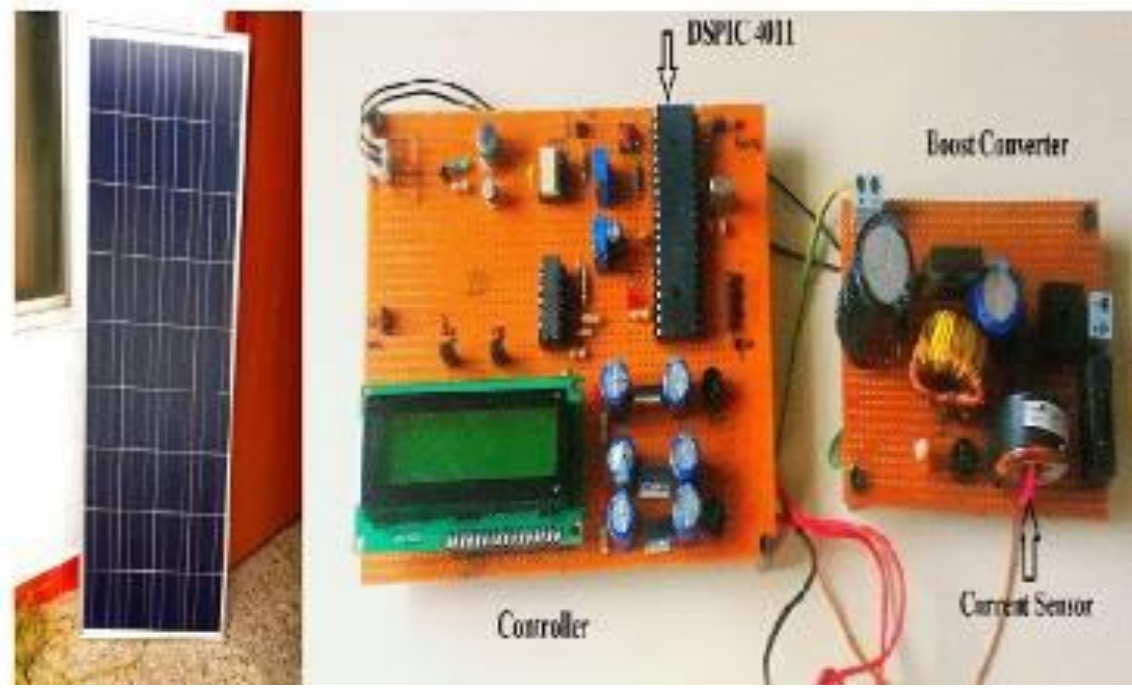

Figure 10. Hardware Setup of MPPT Controller

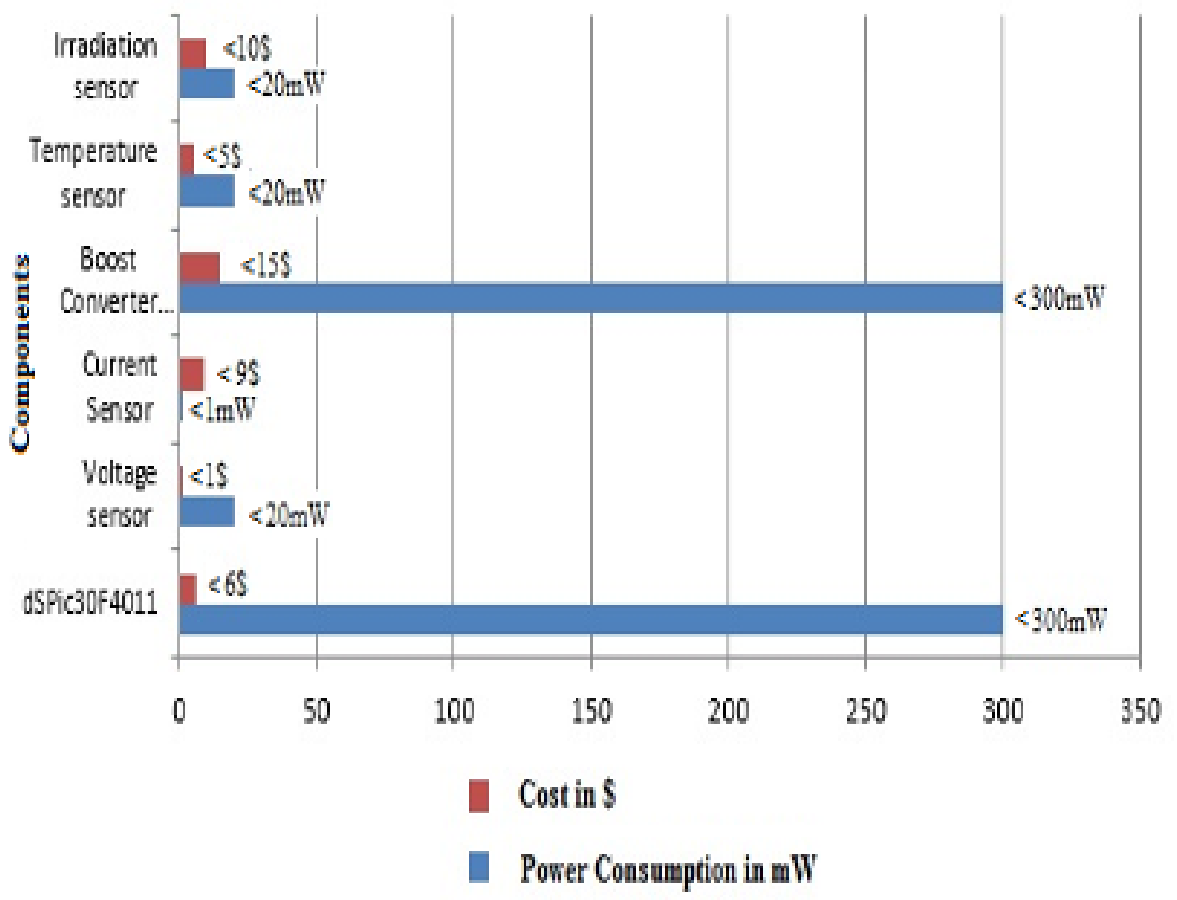

Figure 11. Cost and Power Consumption 
Table 2. Experimental Results

\begin{tabular}{|c|c|c|c|c|}
\hline \multirow{2}{*}{ With MPPT } & Load & Voltage(v) & Current & Power(w) \\
\cline { 2 - 5 } & $80 \mathrm{ohm}$ & $68 \mathrm{~V}$ & $1.85 \mathrm{~A}$ & $126 \mathrm{~W}$ \\
\hline Without MPPT & $80 \mathrm{ohm}$ & $19.7 \mathrm{~V}$ & $0.8 \mathrm{~A}$ & $15 \mathrm{~W}$ \\
\hline
\end{tabular}

\section{Conclusion}

The Objective of this work is to develop a maximum power point tracker that would be able to provide a load with maximum power. This work emphasizes on designing a cheap and stand-alone digital signal controller based solution system which can generate the required control PWM signal for the dc/dc boost converter. The results obtained render a validation for the performance of the system. The MPPT algorithm is realized in hardware using dsPIC 4011 digital signal controller and a boost converter. The performance of the hardware set up proves that the mentioned technique is very simple and effective. This work can be extended for a stand-alone varying load like induction motor including a feed back control.

\section{References}

[1] Solar in India, report by MNRE (Ministry of new and renewable energy), (2010).

[2] A. Luque and S. Hegedus, "Handbook of photovoltaic science and Engineering", John Wiley and Sons Ltd., England, (2003).

[3] A. Dolara, R. Faranda and S. Leva, "Energy comparison of seven MPPT Techniques for PV Systems", Journal of Electromagnetic Analysis and Applications, vol. 1, no. 3, (2009), pp. 152-162.

[4] K. H. Hussein, I. Muta, T. Hoshine and M. Osakada, "Maximum power point tracking: an algorithm for rapidly changing atmospheric conditions", IEE Pro.-Gener. Transm. Distrib., vol. 142, (1995), pp. 59-64.

[5] S. Mehrnami and S. Farhangi, "A fast maximum power point tracking technique for PV powered systems", Industrial Electronics, IECON'09, 35 ${ }^{\text {th }}$ Annual Conference of IEEE, (2009), pp. 42-46.

[6] E. Koutroulis, K. Kalaitzakis and N. C. Voulgaris, "Development of a microcontroller-based photovoltaic maximum power point tracking control system", IEEE Transactions on Power Electronics, vol. 16, no. 1, (2001), pp. 46-54.

[7] W. Xiao, N. Ozog and W. G. Dunford, "Topology study of photovoltaic interface for maximum power point tracking”, IEEE Transactions on Industrial Electronics, vol. 54, no. 3, (2007), pp. 1696-1704.

[8] R. Gules, J. De Pellegrin Pacheco, H. L. Hey and J. Imhoff, “A maximum power point tracking system with parallel connection for PV stand-alone applications", IEEE Transactions on Industrial Electronics, vol. 55, no. 7, (2008), pp. 2674-2683.

[9] X. Liu and L. A. C. Lopes, "An improved perturbation and observation maximum power point tracking for PV arrays", Power Electronics Specialists Conference, IEEE 35 ${ }^{\text {th }}$ Annual, vol. 3, (2004) June, pp. 20052010.

[10] N. Femia, G. Petrone, G. Spagnuolon and M. Vitelli, "Optimization of Perturb and observe maximum power point tracking method", IEEE Transactions on Power Electronics, vol. 20, no. 4, (2005) July, pp. 963-973.

[11] L. Fangrui, D. Shanxu, L. Fei, L. Bangyin and K. Yong, "A variable step size INC MPPT method for PV systems”, IEEE Trans. Ind. Electron., vol. 55, no. 7, (2008) July, pp. 2622 - 2628. 
[12] K. K. Tse, H. S. H. Chung, S. Y. R. Hui and Ho, "A novel maximum power point tracking technique for PV panels”, Power Electronics Specialists Conference, PESC, 2001 IEEE 32nd Annual, vol. 4, (2001), pp. 19701975.

[13] S. M. M. Wolf and J. H. R. Enslin, "PhotoVoltaic Maximum Power Point Tracking Regulator with Simplistic Controller", 24th Annual IEEE Conference of Power Electronics Specialists, (1993), pp. 581 587.

[14] K. Kachhiya, M. Lokhande and M. Patel, "MATLAB/Simulink Model of Solar PV Module and MPPT Algorithm", proceedings of the National Conference on Recent Trends in Engineering and Technology, (2011).

[15] I. H. Atlas and A. M. Sharaf, "A Photovoltaic Array Simulation Model for Matlab-Simulink GUI Environment”, International Conference on Clean Power, (2007), pp. 341-345.

[16] S. Nema, R. K. Nema and G. Agnihotri, "MATLAB/Simulink based study of photovoltaic cells / modules / array and their experimental verification", International journal of Energy and Environment, vol. 1, no. 3, (2010), pp. 487-500.

[17] S. Rustemli and F. Dincer, "Modeling of Photovoltaic Panel and Examining Effects of Temperature in Matlab/Simulink", Electronics and Electrical Engineering, ISSn, 1392-1215, vol. 3, no. 109, pp. 35-40.

[18] M. H. Rashid, "Power Electronics: Circuits, Devices and Operations", Book.

[19] N. Mohan, M. Underland and W. P. Robbins, "Power electronics", $2^{\text {nd }}$ ed. John Wiley and Sons, Inc., (1995).

\section{Authors}

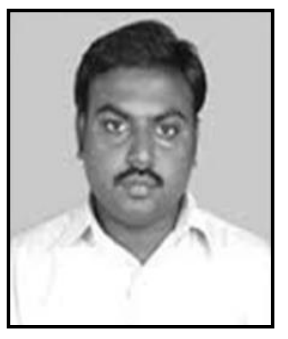

R. Sridhar completed his undergraduate program in Electrical Engineering in 2002 from Arulmigu Kalasalingam College of Engineering, Tamil Nadu, India. He received his M.Tech degree in Power Electronics and Drives from SASTRA University, Tamil Nadu, India. Currently he is pursuing his research in SRM University Tamil Nadu, India. His research interest includes, Power electronic applications to renewable energy power systems and electric drives. He is an active member of the professional societies like IEEE, MISTE SAISE .

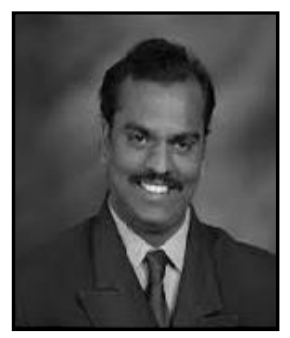

Dr. S. Jeevananthan received B.E.degree in Electrical and Electronics Engineering from MEPCO SCHLENK Engineering College,Sivakasi, India, in 1998, and the M.E. degree from PSG College of Technology, Coimbatore, India ,in 2000.He completed his Ph.D. degree from Pondicherry University in 2007. Since 2001, he has been with the Department of Electrical and Electronics Engineering, Pondicherry Engineering College, Pondicherry, India, where he is an Associate professor. He has made a significant contribution to the PWM theory through his publications and has developed close ties with the international research community in the area. He has authored more than 50 papers published in international and national conference proceedings and professional journals. He regularly reviews papers for all major IEEE TRANSACTIONS in his area and AMSE periodicals (France). He is an active member of the professional societies, IE (India), MISTE. 


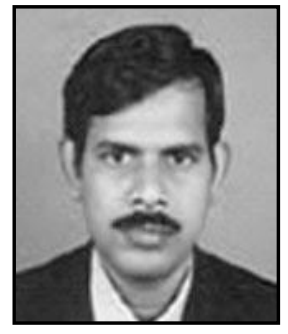

Dr. Subhransu Sekhar Dash received the M.E degree in Electrical Engineering from UCE Burla, Orissa, India and $\mathrm{PhD}$ degree in Electrical Engineering from Anna University in 1996 and 2006 respectively. He is presently working as Professor in SRM University Chennai, India.

His area of interest includes Power Quality, Inverters, Multilevel Inverters, Power System Operation, Control \& Stability, FACTS devices and Intelligent control techniques. He has authored many refereed journals and books.

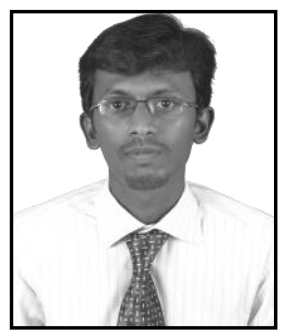

Mr. S. Thomas Michael received the M.Tech degree in Electrical Engineering from SRM University, Chennai, India. He completed B.E in Electrical and Electronics Engineering from Karunya University, Coimbatore, India. His area of interest includes Distributed Generation \& Integrating Renewable energy in Power System. 
International Journal of Control Automation Vol. 7, No. 6, (2014) 